J. Product. \& Dev., 12(2): 347 - 366( 2007)

\title{
EFFECT OF ZINC AND AMINO ACIDS ON GROWTH, YIELD AND CHEMICAL CONSTITUENTS OF CARAWAY ( Carum carvi, L.) PLANTS
}

\author{
A. A. El-Sayed *; EL-Leithy, A. S. *; El-Shorbagy, M. S. ** and Ali, S. A. ** \\ * Ornamental Horticulture Department, Faculty of Agriculture, Cairo University, \\ Egypt. \\ ** Sugar and Integrated Industries Company, Egypt.
}

\begin{abstract}
This study was conducted during two successive seasons of 2003/2004 and 2004/2005 at the Experimental Farm of Ornamental Horticulture Department, Faculty of Agriculture, Cairo University to study the effect of zinc at (0, 50 and $100 \mathrm{ppm})$ and some amino acids, tryptophan at (0,50 and $100 \mathrm{ppm})$ and methionine at (0,25 and $50 \mathrm{ppm})$ on growth, yield, oil production and chemical composition of caraway (Carum carvi, L.) plants. The results showed that zinc application had no significant effect on plant height in the first season, number of branches / plant, dry weight / plant and number of umbels / plant in both seasons. Whereas zinc at $50 \mathrm{ppm}$ significantly increased plant height and dry weight / plant in the second season. Zinc at 50 and 100 ppm significantly increased fresh weight / plant in both two seasons, fruit yield / plant and oil yield/plant in the second one. Zinc at 50 and 100 ppm insignificantly increased oil percentage in both two seasons. Zinc at 50 and 100 ppm decreased limonine percentage in the oil and increased carvone percentage in the oil in both two seasons, total carbohydrates contents in both leaves and roots in the first season. Zinc at 50 ppm increased total carbohydrates in fruits in the first season, while 100 ppm increased it in leaves, fruits and roots in the second one.

Tryptophan and methionine had a significant effect on plant fresh and dry weights in both seasons. The most effective treatment was methionine application at $50 \mathrm{ppm}$. Tryptophan and methionine at $50 \mathrm{ppm}$ gave the highest fruit yield / plant in the first and second seasons, respectively. Amino acids (tryptophan and methionine) insignificantly increased volatile oil percentage and oil yield / plant in the first season. Whereas, methionine at 25 ppm significantly decreased oil percentage in the second season. Methionine at the highest rate $(50 \mathrm{ppm})$ decreased limonene and increased carvone percentages in caraway essential oil in both seasons. Amino acids application increased total carbohydrates percentage in leaves in the first season, in fruits and roots in both two seasons.
\end{abstract}

Interaction between zinc and amino acids (tryptophan and methionine) had a significant effect on most vegetative growth characteristics, fruit yield / plant, oil percentage and oil yield / plant, and 
increased limonine and carvone contents in the oil and total carbohydrates percentage in different plant organs.

Key words: Zinc, amino acids, growth, yield, chemical constituents, caraway, Carum carvi, L plants.

\section{INTRODUCTION}

Caraway (Carum carvi, L.) belongs to family Apiaceae (Umbelliferae) is an annual herb native to Europe and Western Asia and naturalized in North America. An essential oil obtained from the fruit by steam distillation, (Guenther, 1968). The volatile oil is composed mainly of carvone and limonene, with minor amount of carveol, dihydrocarveol, dihydrocarvone, terpenes and others, (Masada, 1976). Concentrations of the components vary, depending on the degree of ripeness of the fruit; contents of carvone and other oxygenated components increase as fruit ripens. Thus oils obtained from fully mature seeds contain more carvone and less limonene and are considered to be better quality. It considered having carminative, stomachic and laxative properties. Oil is used as flavor in pharmaceuticals; it is also used as a fragrance component in cosmetic preparations including toothpaste, mouthwash, soap, creams, lotions, and perfumes (Leung and Foster, 1996). Zinc application affecting growth, yield and chemical constituents of many aromatic plants; Kassem (2002) on rosemary plant; Khalil et al.(2002) on Tagetes erecta and Misra et al.(2005) on geranium.

On the effect of zinc and other trace elements; El- Sawi and Mohamed (2002) on cumin; Sharang et al.(2002) on fennel; Mousa et al.(2001) on Nigella sativa; Mohamed (2003) on Foeniculum vulgare, L. and Aziz and El- Sherbeny (2004) on Sideritis montana.

Amino acids application affecting growth, yield and chemical constituents of many aromatic plants; Mohamed (2003) on fennel; Naguib et al. (2003) on periwinkle plants; Talaat (2005) on Lavandula angustifolia and Talaat et al.(2005) on Cantharanthus roseus, L.

\section{MATERIALS AND METHODS}

This study was conducted during two successive seasons of 2003/2004 and 2004/2005 at the Experimental Farm of Ornamental Horticulture Department, Faculty of Agriculture, Cairo University to study the effect of zinc and some amino acids (tryptophan and methionine ) on growth, yield, oil production and chemical composition of caraway (Carum carvi, L.) plants.

Seeds (fruits) of caraway (Carum carvi, L.) obtained from the Experimental Farm of Faculty of Pharmacy, Cairo University were sown on $15^{\text {th }}$ October in the two seasons in the field on one side of the rows, in hills $30 \mathrm{~cm}$ apart. The experimental plots were $(2.0 \times 4.0 \mathrm{~m})$ with 3 rows at a distance of $60 \mathrm{~cm}$ between rows. Between 
every two beds, there was a ridge $50 \mathrm{~cm}$ wide. The seedlings were thinned one month after sowing to two plants per hill.

The physical and chemical properties of the soil of the experimental area are shown in Tables (A and B). The analysis of the soil was conducted using the method described by Jakson (1967).

The plants were fertilized by NPK fertilizers at a constant level, using ammonium sulphate $(20.5 \% \mathrm{~N})$ at $150 \mathrm{~kg} /$ fed calcium super-phosphate $\left(15.5 \% \mathrm{P}_{2} \mathrm{O}_{5}\right)$ at $100 \mathrm{~kg} / \mathrm{fed}$ and potassium sulphate $\left(48 \% \mathrm{~K}_{2} 0\right)$ at $\quad 50 \mathrm{~kg} / \mathrm{fed}$. The fertilizers added at two equal splits. The first after 45 days from the sowing, and the later one month from the first.

Plants in the main experimental plots were sprayed with zinc( as zinc sulphate) at the rate of 0,50 and $100 \mathrm{ppm} 3$ times, the first one month after sowing, the second was one month after the first and the third one was one month after the second.

Table (A): Mechanical analysis of the soil .

\begin{tabular}{ccccccc}
\hline $\begin{array}{c}\text { Sample } \\
\text { No. }\end{array}$ & $\begin{array}{c}\text { Depth } \\
\text { cm }\end{array}$ & $\begin{array}{c}\text { Coarse } \\
\text { sand }\end{array}$ & $\begin{array}{c}\text { Fine } \\
\text { sand }\end{array}$ & Clay & Silt nn & Texture \\
\hline 1 & $0-20$ & 4.6 & 33.6 & 21.7 & 40.1 & Loamy sand \\
2 & $20-40$ & 5.6 & 30.6 & 25.1 & 38.7 & Loamy sand \\
\hline
\end{tabular}

Table B: Chemical properties of the soil.

\begin{tabular}{|c|c|c|c|c|c|c|c|c|c|c|c|c|}
\hline \multirow{2}{*}{$\begin{array}{l}\text { Depth } \\
\text { (cm) }\end{array}$} & \multirow{2}{*}{$\begin{array}{c}\mathbf{N} \\
(\mathbf{p p m})\end{array}$} & \multirow{2}{*}{$\begin{array}{l}\text { O.M } \\
\%\end{array}$} & $\mathrm{SO}_{4}$ & $\mathrm{Cl}^{-}$ & $\mathrm{HCO}_{3}^{-}$ & $\mathbf{M g}^{++}$ & $\mathbf{C a}^{++}$ & $\mathbf{K}^{+}$ & $\mathbf{N a}^{+}$ & \multirow{2}{*}{$\begin{array}{r}\mathrm{CO3}^{-} \\
\%\end{array}$} & \multirow{2}{*}{$\begin{array}{c}\text { E.C. } \\
(\mathbf{d S} / \mathbf{m})\end{array}$} & \multirow{2}{*}{ pH } \\
\hline & & & \multicolumn{7}{|c|}{ meq /100g soil (aq:soil.1:5) } & & & \\
\hline $0-20$ & 587 & 1.74 & 6.98 & 1.63 & 0.55 & 0.75 & 1.00 & 0.39 & 7.02 & 3.15 & 1.00 & 8.00 \\
\hline $20-40$ & 475 & 1.74 & 2.97 & 1.50 & 0.75 & 0.75 & 1.25 & 0.22 & 3.00 & 3.60 & 0.60 & 8.12 \\
\hline
\end{tabular}

Plants in the sub plots were sprayed with tryptophan at the rate of 0,50 and $100 \mathrm{ppm}$ and methionine at 0,25 and $50 \mathrm{ppm}$. Both tryptophan and methionine were sprayed 3 times, the first one month after the sowing, the second was one month after the first and the third application was one month after the second.

Data on plant height, number of branches / plant, fresh and dry weights of herb (g / plant during milky stage), number of umbels / plant, fruit yield (g / plant). The samples were dried in an electric oven at $70^{\circ} \mathrm{C}$ till a constant weight. Essential oil percentage and oil yield $(\mathrm{ml}) /$ plant were determined as described by British Pharmacopoeia (1963). Gas Liquid chromatography (GLC) analysis of the essential oil was performed using Hewlett Packard gas chromatograph apparatus with the following specifications: Capillary column Ultra 2 (cross-linked 5\% ph. me. Silicone) $25 \mathrm{~m} \times 0.32 \mathrm{~m} \times 0.52 \mu \mathrm{L}$ film thickness. Nitrogen, hydrogen and air flow rates were 30,30 and $300 \mathrm{ml} / \mathrm{min}$, respectively. Injection temperature of $250{ }^{\circ} \mathrm{C}$, Detector temperature of $275^{\circ} \mathrm{C}$, Oven program of $70^{\circ} \mathrm{C}$ to $220^{\circ} \mathrm{C}$, increasing the temperature 
by $10^{\circ} \mathrm{C} / \mathrm{min}$. Chart speed was $1 \mathrm{~cm} / \mathrm{min}$ as described by Bunzen et al.(1969) and total carbohydrates contents were determined as described by Herbert et al. (1971).

The layout of the experiment was split plot design. The main plots were zinc application and the sub- plots were amino acids application, including 15 treatments. Each treatment was replicated 3 times.

The statistical analysis was carried out using Least Significant Difference (LSD) test at $0.05 \%$ according to Snedecor and Cochran (1982).

\section{RESULTS AND DISCUSSION}

\section{Plant height:}

Data presented in Table 1 showed that, in the first season, zinc application at 50 or $100 \mathrm{ppm}$ had no significant effect on plant height as compared with control. In the second season, zinc application at $50 \mathrm{ppm}$ significantly increased plant height compared to control plants. Whereas zinc at $100 \mathrm{ppm}$ had no significant effect compared with untreated plants. These results are in agreement with the findings obtained by Mohamed (2000) on coriander and caraway; and Kassem (2002) on Rosmarinus officinalis. They showed that zinc application increased plant height.

Concerning the effect of amino acids on plant height, data presented in Table 1 showed that amino acids had no significant effect on plant height compared with the control in both seasons. In the second season, methionine application at 25 and 50 ppm significantly increased plant height compared to tryptophan application at 50 and $100 \mathrm{ppm}$. The most effective treatment was methionine at $25 \mathrm{ppm}$ treatment. These results are in harmony with those obtained with Zedan (2000) on Carum carvi and Coriandrum sativum and Mohamed (2003) on fennel. They showed that amino acids application increased plant height.

Concerning interaction between zinc and amino acids, the results showed a significant difference in plant height in both seasons. In the first season, spraying with zinc at $100 \mathrm{ppm}$ and tryptophan at $100 \mathrm{ppm}$ gave the tallest plants compared with zinc application at $50 \mathrm{ppm}$ plus methionine at $50 \mathrm{ppm}$, which gave the shortest plants. In the second season, application of zinc at $50 \mathrm{ppm}$ plus methionine at $25 \mathrm{ppm}$ gave the tallest plants, while tryptophan at $50 \mathrm{ppm}$ plus zinc at $0.00 \mathrm{ppm}$ gave the shortest plants. This increment in plant height may be due to the role of zinc and amino acids on biosynthesis of indole acetic acid ( IAA ) which increase plant height. Similar results were obtained by Mohamed (2003) on fennel, who found that tryptophan at $200 \mathrm{ppm}$ and trace elements at $150 \mathrm{ppm}$ may be recommended to increase plant height.

\section{Number of primary branches /plant:}

Data in Table 1 showed that there were insignificant differences on number of branches per plant due to zinc application at two concentrations in the two seasons as compared with the control. The results of increment or decrement are in harmony with those obtained with Kassem (2000) on rosemary plants and Mohamed (2000) on Coriandrum sativum, L. and Carum carvi, L. 
Table 1: Effect of zinc and amino acids (tryptophan and methionine) on plant height $(\mathrm{cm}$.) and number of branches / plant at milky stage of caraway (Carum carvi, L.) at 2003/2004 and 2004/2005 seasons.

\begin{tabular}{|c|c|c|c|c|c|c|c|c|}
\hline \multirow{2}{*}{$\begin{array}{l}\text { Treatments } \\
\text { Zinc (A) }\end{array}$} & \multicolumn{8}{|c|}{ Plant height } \\
\hline & \multicolumn{4}{|c|}{$2003 / 2004$} & \multicolumn{4}{|c|}{$2004 / 2005$} \\
\hline \multirow[b]{2}{*}{$\begin{array}{l}\text { Amino Acids } \\
\text { ppm (B) }\end{array}$} & \multirow[t]{2}{*}{ Control } & \multicolumn{2}{|c|}{ Zinc ppm } & \multirow[t]{2}{*}{ Mean } & \multirow[t]{2}{*}{ Control } & \multicolumn{2}{|c|}{ Zinc ppm } & \multirow[t]{2}{*}{ Mean } \\
\hline & & 50 & 100 & & & 50 & 100 & \\
\hline Control & 91.30 & 91.20 & 92.53 & 91.68 & 103.70 & 116.30 & 110.20 & 110.10 \\
\hline \multirow{2}{*}{ Tryptophan } & 91.97 & 89.10 & 86.63 & 89.23 & 100.20 & 108.60 & 111.00 & 106.60 \\
\hline & 88.63 & 88.40 & 98.30 & 91.78 & 106.30 & 114.70 & 101.60 & 107.50 \\
\hline \multirow[t]{2}{*}{ Methionine } & 88.77 & 87.40 & 88.10 & 88.09 & 114.40 & 119.40 & 111.70 & 115.20 \\
\hline & 91.50 & 84.53 & 90.17 & 88.73 & 116.50 & 111.40 & 116.10 & 114.70 \\
\hline Mean & 90.43 & 88.13 & 91.15 & $\begin{array}{l}------ \\
\end{array}$ & 108.20 & 114.10 & 110.10 & +----- \\
\hline \multicolumn{9}{|l|}{ LSD at $0.05 \%$ for: } \\
\hline \multirow{3}{*}{$\begin{array}{l}\text { Zinc (A) } \\
\text { Amino acids (B) } \\
\text { AXB }\end{array}$} & \multicolumn{4}{|c|}{ N.S. } & \multicolumn{4}{|c|}{5.37} \\
\hline & \multicolumn{4}{|c|}{ N.S. } & \multicolumn{4}{|c|}{6.94} \\
\hline & \multicolumn{4}{|c|}{9.61} & \multicolumn{4}{|c|}{12.02} \\
\hline & \multicolumn{8}{|c|}{ Number of branches / plant } \\
\hline Control & 7.53 & 7.40 & 8.40 & 7.78 & $10 . .97$ & 10.17 & 8.40 & 9.84 \\
\hline \multirow[t]{2}{*}{ Tryptophan } & 7.40 & 7.77 & 6.63 & 7.27 & 9.17 & 9.20 & 9.30 & 9.22 \\
\hline & 6.97 & 7.00 & 7.30 & 7.09 & 9.53 & 10.63 & 9.17 & 9.78 \\
\hline \multirow[t]{2}{*}{ Methionine } & 6.73 & 7.77 & 6.97 & 7.16 & 8.40 & $10 . .30$ & $10 . .97$ & 9.89 \\
\hline & 6.87 & 6.93 & 7.33 & 7.04 & 9.40 & 9.30 & 10.87 & 9.86 \\
\hline Mean & 7.10 & 7.37 & 7.33 & ---- & 9.49 & 9.92 & 9.74 & ----- \\
\hline \multicolumn{9}{|l|}{ LSD at $0.05 \%$ for: } \\
\hline \multirow{3}{*}{$\begin{array}{l}\text { Zinc (A) } \\
\text { Amino acids (B) } \\
\text { AXB }\end{array}$} & \multicolumn{4}{|c|}{ N.S. } & \multicolumn{4}{|c|}{ N.S. } \\
\hline & \multicolumn{4}{|c|}{ N.S. } & & & & \\
\hline & & & J.S. & & & & & \\
\hline
\end{tabular}

Concerning the effect of amino acids. Data presented in Table 1 showed that tryptophan and methionine treatments had no effect on number of branches /plant in both two seasons. Theses results are in accordance with the findings of Harridy (1986) on Catharnthus roseus, found that tryptophan application at $100 \mathrm{ppm}$ had no effect on number of branches.

Concerning the interaction between zinc and amino acids (Tryptophan and Methionine), there were insignificant differences in number of branches per plant due to all treatments in the first season as compared with control. In the second season, interaction between zinc and amino acids had a significant effect on number of branches/plant. The highest number of branches /plant was obtained for control plants, whereas the lowest number of branches /plant were obtained due to zinc application at $100 \mathrm{ppm}$ or methionine application at $25 \mathrm{ppm}$. 
Fresh weight (g. / Plant):

Data presented in Table 2 showed that zinc application at 50 and $100 \mathrm{ppm}$ significantly increased plant fresh weight in both two seasons. Zinc at $100 \mathrm{ppm}$ was the most effective treatment which gave the heaviest fresh weight in both two seasons. This may be due to zinc contribution in enzymatic and photosynthesis activity, which in turn increase plant fresh weight. This is in accordance with the findings of Mohamed (1998) on Nigella sativa and Kassem (2002) on rosemary. They showed that, zinc application increased herbage fresh weight.

Concerning the effect of amino acids, tryptophan and methionine showed a significant increment in plant fresh weight in the first and second seasons compared with control. The most effective treatments were tryptophan at $50 \mathrm{ppm}$ and methionine at $50 \mathrm{ppm}$ in both seasons, respectively which gave the heaviest fresh weight. Similar results are obtained by Mohamed (2003) on fennel, Naguib et al. (2003) on periwinkle; and Talaat et al.(2005) on periwinkle. They showed that amino acids application increased fresh weight / plant.

Interaction between zinc application and amino acids, spraying significantly affected fresh weight /plant. In the first season, the heaviest plant fresh weight was obtained from plants treated with zinc at $100 \mathrm{ppm}$ plus tryptophan at $100 \mathrm{ppm}$, while the lowest fresh weight was obtained for control plant (without zinc or amino acids applications). In the second season, the heaviest fresh weight was obtained due to zinc at $100 \mathrm{ppm}$ plus methionine at $50 \mathrm{ppm}$ application compared to tryptophan at $50 \mathrm{ppm}$ without zinc application which gave the lowest value. This may be due to amino acids effect on indole acetic acid synthesis which contributes in photosynthesis activity which in turn increases plant fresh weight. Similar results were obtained by Mohamed (2003) on fennel plants, who found that methionine at $50 \mathrm{ppm}$ plus trace-elements at $150 \mathrm{ppm}$ may be recommended to increase fresh weight of plant.

\section{Dry weight of herb:}

Data presented in Table 2 showed that zinc application had no significant effect on dry weight of above ground parts in the first season compared to the untreated plants. On the other hand, in the second season, spraying with zinc at $50 \mathrm{ppm}$ significantly increased dry weight of plants compared with control plants. Similar results were recorded by Rao and Chand (1996) on lemon grass and Kassem (2002) on rosemary plants. They showed that zinc application increased plant dry weight.

Both tryptophan and methionine application significantly increased herb dry weight compared to control. The most effective treatment was methionine application at $50 \mathrm{ppm}$ which gave the heaviest dry weight compared to control plants. In the second season, tryptophan application at $100 \mathrm{ppm}$ and methionine at $25 \mathrm{ppm}$ insignificantly increased dry weight/plant. Whereas methionine at $50 \mathrm{ppm}$ significantly increased dry weight of herb, giving the highest value compared to control plants. This is in accordance with the findings of Naguib et al. (2003) on periwinkle and Talaat et al. (2005) on periwinkle. They found that amino acids increased herb dry weight. 
Table 2: Effect of zinc and amino acids (tryptophan and methionine) on fresh and dry weights (g./ plant) at milky stage of caraway (Carum carvi, L.) at 2003/2004 and 2004/2005 seasons.

\begin{tabular}{|c|c|c|c|c|c|c|c|c|c|}
\hline \multicolumn{2}{|l|}{ Treatments } & \multicolumn{8}{|c|}{ Fresh weight } \\
\hline \multirow{3}{*}{\multicolumn{2}{|c|}{$\begin{array}{c}\text { Zinc (A) } \\
\text { Amino Acids } \\
\text { ppm (B) }\end{array}$}} & \multicolumn{4}{|c|}{$2003 / 2004$} & \multicolumn{4}{|c|}{$2004 / 2005$} \\
\hline & & \multirow[t]{2}{*}{ Control } & \multicolumn{2}{|c|}{ Zinc ppm } & \multirow[t]{2}{*}{ Mean } & \multirow[t]{2}{*}{ Control } & \multicolumn{2}{|c|}{ Zinc ppm } & \multirow[t]{2}{*}{ Mean } \\
\hline & & & 50 & 100 & & & 50 & 100 & \\
\hline Control & & 111.9 & 155.4 & 146.6 & 138.0 & 268.2 & 252.1 & 215.7 & 245.3 \\
\hline \multirow[t]{2}{*}{ Tryptophan } & 50 & 200.5 & 204.4 & 208.8 & 204.6 & 153.3 & 308.0 & 325.3 & 262.2 \\
\hline & 100 & 138.2 & 207.5 & 260.9 & 202.2 & 315.7 & 238.4 & 295.4 & 283.2 \\
\hline \multirow[t]{2}{*}{ Methionine } & 25 & 124.8 & 184.3 & 196.3 & 168.5 & 242.2 & 339.9 & 310.2 & 297.5 \\
\hline & 50 & 240.4 & 188.0 & 162.3 & 196.9 & 276.9 & 294.7 & 361.1 & 310.9 \\
\hline Mean & & 163.2 & 187.9 & 195.0 & -ב---- & 251.3 & 286.6 & 301.5 & ----- \\
\hline \multicolumn{10}{|c|}{ LSD at $0.05 \%$ for: } \\
\hline \multicolumn{2}{|c|}{ Zinc (A) } & \multicolumn{4}{|c|}{22.6} & \multicolumn{4}{|c|}{35.1} \\
\hline \multirow{2}{*}{\multicolumn{2}{|c|}{$\begin{array}{l}\text { Amino acids (B) } \\
\text { AXB }\end{array}$}} & \multicolumn{4}{|c|}{29.2} & \multicolumn{4}{|c|}{45.3} \\
\hline & & \multicolumn{3}{|c|}{50.6} & & \multicolumn{4}{|c|}{78.5} \\
\hline & & \multicolumn{8}{|c|}{ Dry weight } \\
\hline \multicolumn{2}{|l|}{ Control } & 20.74 & 35.88 & 34.17 & 30.26 & 60.74 & 71.38 & 33.90 & 55.34 \\
\hline \multirow[t]{2}{*}{ Tryptophan } & 50 & 44.78 & 41.53 & 50.39 & 45.57 & 29.04 & 67.27 & 51.84 & 49.38 \\
\hline & 100 & 28.70 & 47.94 & 34.43 & 37.03 & 71.69 & 53.86 & 53.65 & 59.73 \\
\hline \multirow[t]{2}{*}{ Methionine } & 25 & 49.40 & 34.67 & 41.39 & 41.82 & 50.66 & 76.24 & 63.82 & 63.57 \\
\hline & 50 & 70.38 & 43.04 & 38.02 & 50.48 & 57.42 & 62.19 & 78.65 & 66.08 \\
\hline \multicolumn{2}{|l|}{ Mean } & 42.80 & 40.61 & 39.68 & - & 53.91 & 66.19 & 56.37 & --- \\
\hline \multicolumn{10}{|c|}{ LSD at $0.05 \%$ for: } \\
\hline \multicolumn{2}{|c|}{$\operatorname{Zinc}(\mathbf{A})$} & \multicolumn{4}{|c|}{ N.S. } & \multicolumn{4}{|c|}{7.02} \\
\hline \multicolumn{2}{|c|}{ Amino acids (B) } & & 6. & & & & & & \\
\hline AXB & & & 10 & & & & & & \\
\hline
\end{tabular}

Interaction between zinc and amino acids, application had a significant effect on herb dry weight. In the first season, plants treated without zinc (control) plus methionine at $50 \mathrm{ppm}$ gave the heaviest dry weight compared with control plants (without zinc or amino acids) which gave the lowest value. In the second season, plants sprayed with zinc at $100 \mathrm{ppm}$ plus methionine at $50 \mathrm{ppm}$ gave the heaviest dry weight compared with plants treated with zinc at $100 \mathrm{ppm}$ without amino acids application which gave the lowest value.

\section{Number of umbels per plant :}

Data recorded in Table 3 showed that, in the first season, zinc application had no significant effect on number of umbels/plant compared with control. Zinc application at $100 \mathrm{ppm}$ gave the highest value compared to zinc application at $50 \mathrm{ppm}$ with a significant difference. In the second season, zinc application had no significant effect on number of umbels /plant compared with the control. The obtained results 
Table 3: Effect of zinc and amino acids (tryptophan and methionine) on number of umbels / plant and fruit yield (g. / plant) of caraway (Carum carvi, L.) at 2003/2004 and 2004/2005 seasons.

\begin{tabular}{|c|c|c|c|c|c|c|c|c|}
\hline \multirow{4}{*}{\begin{tabular}{l} 
Treatments \\
\multicolumn{1}{c}{ Zinc (A) } \\
Amino Acids \\
ppm (B)
\end{tabular}} & \multicolumn{8}{|c|}{ Number of umbels / plant } \\
\hline & \multirow{3}{*}{ Control } & \multicolumn{3}{|c|}{ 2003/2004 } & \multicolumn{4}{|c|}{$2004 / 2005$} \\
\hline & & \multicolumn{2}{|c|}{ Zinc ppm } & \multirow[t]{2}{*}{ Mean } & \multirow[t]{2}{*}{ Control } & \multicolumn{2}{|c|}{ Zinc ppm } & \multirow[t]{2}{*}{ Mean } \\
\hline & & 50 & 100 & & & 50 & 100 & \\
\hline Control & 41.73 & 47.33 & 54.53 & 47.87 & 45.11 & 49.56 & 57.39 & 50.69 \\
\hline \multirow[t]{2}{*}{ Tryptophan } & 57.63 & 43.33 & 62.30 & 54.42 & 40.34 & 57.44 & 50.22 & 49.33 \\
\hline & 39.97 & 43.50 & 49.50 & 44.32 & 33.28 & 48.78 & 42.78 & 41.61 \\
\hline \multirow[t]{2}{*}{ Methionine } & 59.40 & 42.07 & 54.20 & 51.89 & 40.61 & 49.67 & 51.78 & 47.35 \\
\hline & 63.07 & 57.40 & 49.79 & 56.75 & 54.66 & 45.39 & 44.94 & 48.33 \\
\hline Mean & 52.36 & 46.73 & 54.06 & ------ & 42.80 & 50.17 & 49.42 & ----- \\
\hline \multicolumn{9}{|l|}{ LSD at $0.05 \%$ for: } \\
\hline Zinc (A) & \multicolumn{4}{|c|}{6.87} & \multicolumn{4}{|c|}{ N.S. } \\
\hline Amino acids (B) & \multirow{2}{*}{\multicolumn{4}{|c|}{$\begin{array}{c}8.87 \\
1537\end{array}$}} & \multicolumn{4}{|c|}{ N.S. } \\
\hline AXB & & & & & \multicolumn{4}{|c|}{18.79} \\
\hline & \multicolumn{3}{|c|}{15.37} & \multicolumn{2}{|c|}{ Fruit yield } & & & \\
\hline Control & 8.13 & 9.93 & 11.25 & 9.77 & 18.67 & 25.30 & 23.75 & 22.57 \\
\hline \multirow{2}{*}{ Tryptophan } & 9.27 & 10.53 & 11.17 & 10.33 & 23.50 & 24.45 & 23.25 & 23.73 \\
\hline & 7.86 & 10.76 & 11.91 & 10.18 & 18.40 & 25.10 & 23.57 & 22.36 \\
\hline \multirow[t]{2}{*}{ Methionine } & 9.88 & 9.40 & 10.69 & 9.99 & 19.53 & 29.33 & 24.13 & 24.33 \\
\hline & 11.28 & 10.40 & 8.98 & 10.22 & 23.50 & 21.13 & 28.75 & 24.46 \\
\hline Mean & 9.29 & 10.20 & 10.80 & ----- & 20.72 & 25.06 & 24.69 & ----- \\
\hline \multicolumn{9}{|l|}{ LSD at $0.05 \%$ for: } \\
\hline \multirow{2}{*}{$\begin{array}{l}\text { Zinc (A) } \\
\text { Amino acids (B) }\end{array}$} & \multicolumn{4}{|c|}{ N.S. } & \multicolumn{4}{|c|}{3.16} \\
\hline & \multicolumn{4}{|c|}{ N.S. } & \multicolumn{4}{|c|}{ N.S. } \\
\hline AXB & \multicolumn{4}{|c|}{ N.S. } & & 7.0 & & \\
\hline
\end{tabular}

agreed with those obtained by El- Shorbagy (1979) on anise, who noticed that the low concentration of zinc did not affected fruit umbels /plant.

Concerning the effect of amino acids on number of umbels per plant. Amino acids (tryptophan and methionine) had no significant effect on number of umbels /plant compared with control plants in both two seasons. The obtained results are disagreement with those obtained by Mohamed (2003) on fennel, who found that both tryptophan and methionine at 50 and 100 ppm increased number of umbels /plant.

Concerning the interaction between zinc and amino acids the results showed a significant difference. In the first season, methionine application at $50 \mathrm{ppm}$ without zinc $(0.0 \mathrm{ppm})$ gave the highest number of umbels /plant. Whereas control plants (without zinc or amino acids) or tryptophan treatment at $100 \mathrm{ppm}$ gave the lowest values. In the second season, tryptophan at $50 \mathrm{ppm}$ plus zinc at $50 \mathrm{ppm}$ treatments gave the highest values. Whereas tryptophan at $100 \mathrm{ppm}$ without zinc application gave the lowest value. These results are in harmony with those obtained with Mohamed (2003) on fennel. 


\section{Fruit yield / plant:}

Data presented in Table 3 showed that zinc application at 50 and 100 ppm slightly increased fruit yield / plant. Zinc at 100 ppm gave the highest value compared with untreated plants. This increment was statistically insignificant in the first season. In the second season, zinc at 50 and 100 ppm significantly increased fruit yield / plant. Zinc at $50 \mathrm{ppm}$ gave the highest fruit yield followed by zinc treatment at $100 \mathrm{ppm}$ compared with control plants which gave the lowest value. These results are in harmony with those obtained by Mohamed (2000) on coriander and caraway plants. They found that zinc application increased fruit yield / plant.

Amino acids (tryptophan and methionine), slightly increased fruit yield / plant. Tryptophan at $50 \mathrm{ppm}$ and methionine at $50 \mathrm{ppm}$ gave the highest fruit yield / plant in the first and second seasons, respectively. These increments were statistically insignificant compared with control plants.

Regarding the interaction effect between zinc and amino acids, in the first season, there was no significant effect on fruit yield /plant. However the highest fruit yield / plant were obtained from plants treated with zinc at $100 \mathrm{ppm}$ and tryptophan at $100 \mathrm{ppm}$. In the second season, there was a significant effect on fruit yield / plant. The highest values were produced from plants treated with zinc at $50 \mathrm{ppm}$ plus methionine at $25 \mathrm{ppm}$ or zinc at $100 \mathrm{ppm}$ plus methionine at $50 \mathrm{ppm}$ compared with control (without zinc or amino acids) which gave the lowest value. These results are in agreement with those obtained by Mohamed (2003) on fennel, who found that interaction between zinc and tryptophan increased fruit yield / plant.

\section{Volatile oil percentage}

Data presented in Table 4 show that zinc application at 50 or 100 ppm slightly increased volatile oil percentage in both two seasons. Zinc application at 50 and 100 ppm gradually increased volatile oil percentage. These increments were statistically insignificant compared to untreated plants. These results are in harmony with those obtained by Mohamed (2000) on coriander and caraway plants. Who showed that zinc application increased volatile oil percentage.

Amino acids (tryptophan and methionine) insignificantly increased volatile oil percentage compared with control plants in the first season. In the second season, tryptophan at 50 and $100 \mathrm{ppm}$ had no significant effect on volatile oil percentage. On the other hand, methionine at $25 \mathrm{ppm}$ significantly decreased oil percentage compared with untreated plants. Whereas, methionine at $50 \mathrm{ppm}$ insignificantly decreased volatile oil percentage. These results are in agreement with those obtained by Zedan (2000) on coriander and caraway plants showed that tryptophan at 25 and $50 \mathrm{ppm}$ increased volatile oil percentage in the two seasons. Mohamed (2003) on fennel, found that tryptophan and methionine at 100 and $200 \mathrm{ppm}$ increased oil percentage.

Intercalation between zinc and amino acids had a significant effect on oil percentage in both seasons. In the first season, plants treated with tryptophan at 100 ppm plus zinc at $100 \mathrm{ppm}$ gave the highest oil percentage $(1.970 \%)$ followed by plants treated with methionine at $50 \mathrm{ppm}$ plus zinc at $100 \mathrm{ppm}(1.753 \%)$ compared with control plants (without amino acids or zinc), control plants sprayed with zinc at 
Table 4: Effect of zinc and amino acids (tryptophan and methionine) on essential oil percentage (\%) andoil yield ( $\mathrm{ml} /$ plant) of caraway (Carum carvi, L.) at 2003/2004 and 2004/2005 seasons.

\begin{tabular}{|c|c|c|c|c|c|c|c|c|c|}
\hline \multirow{4}{*}{\multicolumn{2}{|c|}{$\begin{array}{c}\text { Treatments } \\
\text { Zinc (A) } \\
\text { Amino Acids } \\
\text { ppm (B) }\end{array}$}} & \multicolumn{8}{|c|}{ Essential oil percentage } \\
\hline & & \multicolumn{4}{|c|}{$2003 / 2004$} & \multicolumn{4}{|c|}{$2004 / 2005$} \\
\hline & & \multirow{2}{*}{$\begin{array}{l}\text { Control } \\
\end{array}$} & \multicolumn{2}{|c|}{ Zinc ppm } & \multirow[t]{2}{*}{ Mean } & \multirow[t]{2}{*}{ Control } & \multicolumn{2}{|c|}{ Zinc ppm } & \multirow[t]{2}{*}{ Mean } \\
\hline & & & 50 & 100 & & & 50 & 100 & \\
\hline Control & & 1.327 & 1.503 & 1.297 & 1.376 & 1.690 & 1.750 & 1.767 & 1.736 \\
\hline \multirow[t]{2}{*}{ Tryptophan } & 50 & 1.630 & 1.167 & 1.360 & 1.386 & 1.900 & 1.627 & 1.807 & 1.774 \\
\hline & 100 & 1.293 & 1.613 & 1.970 & 1.626 & 1.687 & 1.633 & 1.687 & 1.669 \\
\hline \multirow[t]{2}{*}{ Methionine } & 25 & 1.570 & 1.533 & 1.287 & 1.463 & 1.493 & 1.620 & 1.467 & 1.527 \\
\hline & 50 & 1.380 & 1.693 & 1.753 & 1.609 & 1.400 & 1.680 & 1.847 & 1.642 \\
\hline Mean & & 1.440 & 1.502 & 1.533 & --- & 1.634 & 1.660 & 1.715 & $\begin{array}{l}---- \\
\end{array}$ \\
\hline \multicolumn{10}{|c|}{ LSD at $0.05 \%$ for: } \\
\hline \multicolumn{2}{|c|}{ Zinc (A) } & \multicolumn{4}{|c|}{ N.S. } & \multicolumn{4}{|c|}{ N.S. } \\
\hline Amino acic & $s$ (B) & \multicolumn{4}{|c|}{ N.S. } & \multicolumn{4}{|c|}{0.164} \\
\hline \multicolumn{2}{|l|}{$\mathbf{A X B}$} & \multicolumn{3}{|c|}{0.598} & & \multicolumn{4}{|c|}{0.285} \\
\hline & & \multicolumn{8}{|c|}{ Oil yield } \\
\hline \multicolumn{2}{|l|}{ Control } & 0.113 & 0.148 & 0.146 & 0.136 & 0.294 & 0.443 & 0.420 & 0.386 \\
\hline \multirow[t]{2}{*}{ Tryptophan } & 50 & 0.151 & 0.128 & 0.151 & 0.143 & 0.395 & 0.395 & 0.422 & 0.404 \\
\hline & 100 & 0.102 & 0.176 & 0.234 & 0.171 & 0.310 & 0.394 & 0.396 & 0.367 \\
\hline \multirow[t]{2}{*}{ Methionine } & 25 & 0.155 & 0.142 & 0.138 & 0.145 & 0.302 & 0.473 & 0.351 & 0.375 \\
\hline & 50 & 0.156 & 0.204 & 0.155 & 0.171 & 0.330 & 0.353 & 0.535 & 0.406 \\
\hline
\end{tabular}

Mean

$100 \mathrm{ppm}$, tryptophan at $50 \mathrm{ppm}$ plus zinc at $50 \mathrm{ppm}$ and plants treated with tryptophan at $100 \mathrm{ppm}$ without zinc application which gave $(1.327,1.297,1.167$ and $1.293 \%$, respectively. In the second season, plants treated with tryptophan at $50 \mathrm{ppm}$ (without zinc application), tryptophan at $50 \mathrm{ppm}$ plus zinc at $100 \mathrm{ppm}$ and methionine at 50 ppm plus zinc at $100 \mathrm{ppm}$ gave the highest essential oil percentages $(1.900,1.807$ and $1.847 \%$, respectively) compared with plants treated with methionine at $50 \mathrm{ppm}$ (without zinc application) which gave the lowest value (1.400\%).

\section{Volatile oil yield / plant:}

Data in Table 4 showed that zinc application at 50 and 100 ppm gradually increased volatile oil yield / plant compared with control. This increment was statistically insignificant in the first season. On the other hand, in the second season, zinc at 50 and $100 \mathrm{ppm}$ significantly increased volatile oil yield / plant compared to control plants. This effect may be due to the effect of zinc on increase volatile oil percentage and fruit yield / plant. These results are in accordance with the findings obtained by Mohamed (2000) on coriander and caraway and Khalil et al. (2002) on Tagetes erecta. They showed that zinc application increased volatile oil yield / plant. 
Amino acids (both tryptophan and methionine) at different concentrations insignificantly increased volatile oil yield / plant in the first season. While in the second season, tryptophan at $100 \mathrm{ppm}$ and methionine at $25 \mathrm{ppm}$ insignificantly decreased volatile oil yield / plant compared with untreated plants.

Intercalation between zinc and amino acids had a significant effect on volatile oil yield /plant in both two seasons. In the first season, tryptophan at $100 \mathrm{ppm}$ plus zinc at $100 \mathrm{ppm}$ treatment gave the highest oil yield /plant compared with control (without amino acids or zinc), tryptophan at $50 \mathrm{ppm}$ plus zinc at $50 \mathrm{ppm}$ and tryptophan at $100 \mathrm{ppm}$ without zinc application which gave the lowest oil yield/plant. In the second season, methionine at $50 \mathrm{ppm}$ plus zinc application at $100 \mathrm{ppm}$ treatment gave the highest oil yield / plant compared with the control (without amino acids or zinc application) which gave the lowest essential oil yield / plant.

\section{GLC analysis of the essential oil:}

Data presented in Table 5 and Figures (1, 2, 3 and 4) showed that the main components of caraway essential oil are limonene (which ranged from 25.23 to 35.58 $\%$ ) and carvone (which ranged from 57.98 to $72.17 \%$ ). These results are in agreement with those obtained by Guenther (1968).

Zinc application at 50 and $100 \mathrm{ppm}$ decreased limonine percentages in the first and second seasons compared to untreated plants which gave the highest limonine percentage in both seasons.

On the contrary, zinc application at $50 \mathrm{ppm}$ increased carvone percentage, which gave the highest values $(65.34$ and $66.47 \%)$ in both seasons, respectively compared to control or zinc application at $100 \mathrm{ppm}$, which gave the lowest value.

These results are in agreements with the findings obtained by Abou Zaid et. al., (1996) on fennel, showed that zinc treatments increased fenchone and anethole percentages in the oil. Jacoub (1995) on Ocimum basilicum, showed that $\mathrm{Zn}$ application individually or with $\mathrm{Fe}$ and $\mathrm{Mn}$ increased linalool and decreased methyl chavicol percentages in oil. Abd El-Salam (1999) on fennel, showed that Fe, Mn and $\mathrm{Zn}$ at $100 \mathrm{ppm}$ increased fenchone contents. Mohamed (2003) on fennel, showed that, $\mathrm{Fe}, \mathrm{Mn}$ and $\mathrm{Zn}$ at 75 and $150 \mathrm{ppm}$ increased anethole and carvone percentages. While methyl chavicol, fenchone and limonene tended to decrease especially with $150 \mathrm{ppm}$.

Tryptophan application had no clear trend on the essential oil components in both seasons. Tryptophan at $50 \mathrm{ppm}$ decreased both limonene and carvone percentages in the first season. While increased limonene and decreased carvone percentages in the second season. Tryptophan at $100 \mathrm{ppm}$ had no clear tend; i.e it increased limonene and decreased carvone percentages in the first season. In the second season, Tryptophan at $100 \mathrm{ppm}$ gave an opposite trend; i.e. it decreased limonene and increased carvone percentage compared to control plants.

Methionine application at 25 and $50 \mathrm{ppm}$ decreased limonene and increased carvone contents in the first season. In the second season, methionine application had a different effect. Methionine at $25 \mathrm{ppm}$ increased limonene and decreased carvone percentages. Whereas methionine at $50 \mathrm{ppm}$ decreased limonene and increased carvone contents. 
Table 5: Effect of zinc and amino acids (Tryptophan and Methinoine) on GLC analysis of the essential oil of caraway ( Carum carvi, L ) plants at 2003 / 2004 and 2004 / 2005 seasons.

\begin{tabular}{|c|c|c|c|c|c|c|}
\hline \multicolumn{3}{|c|}{ Treatments } & \multicolumn{2}{|c|}{$2003 / 2004$} & \multicolumn{2}{|c|}{$2004 / 2005$} \\
\hline $\begin{array}{l}\text { Zinc } \\
\text { ppm }\end{array}$ & \multicolumn{2}{|c|}{ Amino acids ppm } & Limonine & Carvone & Limonime & Carvone \\
\hline \multirow{5}{*}{ Control } & \multicolumn{2}{|l|}{ Control } & 30.64 & 66.78 & 34.05 & 64.16 \\
\hline & Tryptophan & 50 & 33.85 & 63.04 & 33.78 & 64.47 \\
\hline & & 100 & 33.04 & 64.31 & 31.53 & 66.70 \\
\hline & Methionine & 25 & 32.73 & 64.02 & 32.25 & 65.70 \\
\hline & & 50 & 31.38 & 66.03 & 31.09 & 66.97 \\
\hline & Mean & & 32.32 & 64.84 & 32.54 & 65.60 \\
\hline \multirow{5}{*}{50} & Control & & 37.21 & 59.58 & 31.50 & 66.77 \\
\hline & \multirow{2}{*}{ Tryptophan } & 50 & 33.50 & 62.72 & 32.27 & 65.91 \\
\hline & & 100 & 35.58 & 61.83 & 31.03 & 67.27 \\
\hline & \multirow{2}{*}{ Methionine } & 25 & 27.03 & 70.62 & 33.17 & 64.87 \\
\hline & & 50 & 25.23 & 72.17 & 30.54 & 67.55 \\
\hline & Mean & & 31.71 & 65.38 & 31.70 & 66.47 \\
\hline \multirow{5}{*}{100} & Control & & 33.5 & 62.72 & 30.25 & 68.02 \\
\hline & Tryptophan & 50 & 29.02 & 57.98 & 34.31 & 63.97 \\
\hline & & 100 & 35.19 & 61.06 & 30.82 & 67.29 \\
\hline & \multirow[t]{2}{*}{ Methionine } & 25 & 31.88 & 65.14 & 32.60 & 65.65 \\
\hline & & 50 & 30.65 & 66.83 & 32.45 & 65.88 \\
\hline & Mean & & 32.05 & 62.75 & 32.09 & 66.16 \\
\hline \multicolumn{2}{|c|}{ Control } & & 33.87 & 63.03 & 31.93 & 66.32 \\
\hline \multirow{2}{*}{\multicolumn{2}{|c|}{ Tryptophan }} & 50 & 32.12 & 61.25 & 33.45 & 64.78 \\
\hline & & 100 & 34.60 & 62.40 & 31.13 & 67.09 \\
\hline \multirow{2}{*}{\multicolumn{2}{|c|}{ Methionine }} & 25 & 30.55 & 66.59 & 32.67 & 65.41 \\
\hline & & 50 & 29.09 & 68.34 & 31.36 & 66.80 \\
\hline
\end{tabular}

\section{Mean}


In general, it could be concluded that methionine at the highest rate (50 ppm) decreased limonene and increased carvone percentages in caraway essential oil in both two seasons. Whereas methionine at $25 \mathrm{ppm}$ had no clear trend in both two seasons.

These results are in harmony with those obtained by Milad (1998) showed that carvone, piperitenone oxide and camphore were decreased in Mentha viridis, Mentha longifolia and Ocimum canum, respectively. Zedan (2000) showed that, tryptophan at $25 \mathrm{ppm}$ increased carvone in Carum carvi oil in the two seasons. Limonene showed an adverse trend, dihydro-carveol reduced by tryptophan at 25 and $50 \mathrm{ppm}$. On Coriandrum sativum, tryptophan treatments increased linalool in the first season only. Tryptophan at $25 \mathrm{ppm}$ increased limonene and $\alpha$ pinene in the second season. Mohamed (2003) on fennel, found that anethole percentage was increased by tryptophan and decreased by methionine. Limonene percentage was increased by methionine at $100 \mathrm{ppm}$ and decreased by tryptophan. Fenchone percentage was increased by $100 \mathrm{ppm}$ methionine.

Concerning the interaction effect, tryptophan application at $100 \mathrm{ppm}$ with zinc application $50 \mathrm{ppm}$ gave the highest limonene content in the first season. While in the second season, zinc application at $100 \mathrm{ppm}$ plus tryptophan at $50 \mathrm{ppm}$ gave the highest limonene content in the essential oil of caraway plant.

In the first season, zinc application at $50 \mathrm{ppm}$ plus methionine application at $50 \mathrm{ppm}$ gave the highest carvone content in the essential oil. Whereas zinc application at the highest rate $(100 \mathrm{ppm})$ without amino acids application gave the highest carvone content in the essential oil in the second season.

\section{3- Total carbohydrates percentages :}

Data presented in Table 6 show the effect of zinc and amino acids on total carbohydrates percentage in leaves, fruits and roots. It could be discussed as follows:

\section{A- Total carbohydrates percentage in leaves:}

Zinc application at 50 and $100 \mathrm{ppm}$ increased total carbohydrates percentage in leaves in the first season. The most effective treatment was zinc at $50 \mathrm{ppm}$, which gave the highest value compared to control plants. In the second season, zinc at 100 ppm gave the highest total carbohydrates percentage compared to control plants.

Amino acid (tryptophan) at 50 and $100 \mathrm{ppm}$ and methionine at $50 \mathrm{ppm}$ increased total carbohydrates percentage in the leaves of caraway plants in the first season. On the other hand, in the second season, tryptophan and methionine application decreased total carbohydrates percentage in leaves of caraway plants.

Concerning the effect of interaction, the data in Table 6 showed that plants treated with zinc at $50 \mathrm{ppm}$ and tryptophan at 50 or $100 \mathrm{ppm}$ gave the highest total carbohydrates percentage in the first season. On the other hand, in the second season, zinc at $100 \mathrm{ppm}$ (without amino acids application) gave the highest total carbohydrates percentage in the leaves. 
Table 6: Effect of zinc and amino acids (tryptophan and methionine) on total carbohydrates (\%) in leaves, fruits and roots of caraway (Carum carvi, L.) at 2003 / 2004 and 2004 / 2005 seasons.

\begin{tabular}{|c|c|c|c|c|c|c|c|c|c|}
\hline Treatments & & & & & In le & ives. & & & \\
\hline Zinc (A & & & 2003 & 2004 & & & 200 & 2005 & \\
\hline & & Control & Zinc & ppm & Mean & Control & Zinc & pm & Mean \\
\hline $\begin{array}{r}\text { Amin } \\
\text { ppm }\end{array}$ & $\begin{array}{l}\text { Acids } \\
\text { (B) }\end{array}$ & & 50 & 100 & & & 50 & 100 & \\
\hline Control & & 35.6 & 31.2 & 33.6 & 33.47 & 28.8 & 20.6 & 31.2 & 26.87 \\
\hline Tryptophan & 50 & 34.4 & 44.8 & 31.2 & 36.80 & 18.4 & 25.2 & 28.6 & 24.07 \\
\hline & 100 & 29.2 & 45.2 & 35.6 & 36.67 & 20.2 & 20.4 & 20.2 & 20.27 \\
\hline Methionine & 25 & 28.6 & 35.6 & 36.0 & 33.40 & 26.6 & 20.0 & 27.4 & 24.67 \\
\hline & $\mathbf{5 0}$ & 36.0 & 43.0 & 36.0 & 35.33 & 28.4 & 25.8 & 23.4 & 25.87 \\
\hline Mean & & 32.76 & 39.96 & 34.48 & -- & 24.48 & 22.8 & 26.16 & -- \\
\hline & & & & & In fr & uits. & & & \\
\hline Control & & 25.2 & 22.2 & 27.4 & 24.93 & 17.8 & 20.2 & 20.6 & 19.53 \\
\hline Tryptophan & 50 & 28.8 & 32.0 & 24.8 & 28.53 & 22.6 & 17.0 & 20.0 & 19.87 \\
\hline & 100 & 23.8 & 24.0 & 21.6 & 23.13 & 19.4 & 19.2 & 23.8 & 20.73 \\
\hline Methionine & 25 & 24.6 & 27.8 & 24.6 & 25.67 & 17.8 & 18.4 & 25.8 & 20.77 \\
\hline & 50 & 25.4 & 23.8 & 25.4 & 24.87 & 22.2 & 19.4 & 21.2 & 20.93 \\
\hline Mean & & 25.56 & 25.96 & 24.76 & --- & 19.96 & 18.84 & 22.3 & -- \\
\hline & & & & & In 1 & oots. & & & \\
\hline Control & & 21.6 & 35.2 & 38.6 & 31.8 & 31.5 & 39.6 & 39.8 & 36.98 \\
\hline Tryptophan & 50 & 24.0 & 38.6 & 43.0 & 35.2 & 40.6 & 37 & 42.0 & 40.1 \\
\hline & 100 & 42.6 & 38.4 & 44.8 & 41.9 & 40.8 & 35.6 & 43.6 & 40.0 \\
\hline Methionine & 25 & 41.6 & 35.6 & 41.6 & 39.6 & 43.2 & 42.4 & 37.8 & 41.13 \\
\hline & 50 & 36.4 & 39.0 & 42.6 & 39.3 & 42.2 & 41.8 & 38.8 & 40.9 \\
\hline Mean & & 33.24 & $\mathbf{3 7 . 3 6}$ & 42.12 & --- & 39.7 & 39.4 & 40.4 & --- \\
\hline
\end{tabular}

\section{B- Total carbohydrates percentage in fruits:}

Data presented in Table 6 showed that, zinc application at $50 \mathrm{ppm}$ slightly increased total carbohydrates percentage in the fruits in the first season, while zinc application at $100 \mathrm{ppm}$ decreased carbohydrates percentage compared with control. On the contrary, in the second season, zinc application at $100 \mathrm{ppm}$ increased total carbohydrates percentage in the fruits, while zinc at $50 \mathrm{ppm}$ decreased it.

Tryptophan at $50 \mathrm{ppm}$ and methionine at $25 \mathrm{ppm}$ increased total carbohydrates percentage in the fruits in the first season. In the second season both tryptophan at 50 and $100 \mathrm{ppm}$ and methionine at 25 and $50 \mathrm{ppm}$ increased total carbohydrates percentage in the fruits of caraway plants compared with untreated plants.

Interaction between zinc at $50 \mathrm{ppm}$ and tryptophan at $50 \mathrm{ppm}$ gave the highest total carbohydrates percentage in the first season. Whereas zinc application at 100 ppm plus methionine at $25 \mathrm{ppm}$ gave the highest carbohydrates percentage in the second season. 


\section{C- Total carbohydrates percentage in the roots:}

Data presented in Table 6 showed that zinc application at 50 and $100 \mathrm{ppm}$ increased carbohydrate percentage in the roots in the first season. In the second season, zinc application at $100 \mathrm{ppm}$ increased total carbohydrates percentage in the roots compared with the control plants which gave the lowest value.

Both amino acids (tryptophan at 50 and 100 ppm and methionine at 25 and 50 ppm) increased total carbohydrates percentage in the roots of caraway plants in both two seasons as compared with the untreated plants.

Interaction between zinc at 100ppm and tryptophan at $100 \mathrm{ppm}$ gave the highest total carbohydrates percentage in both first and second seasons as compared with the control plants, which gave the lowest values in both two seasons.

Generally, it could be concluded that zinc application at 50 and $100 \mathrm{ppm}$ increased total carbohydrates percentage in both leaves and roots in the first season, zinc at $50 \mathrm{ppm}$ increased carbohydrates percentage in the fruits in the first season. While zinc application at $100 \mathrm{ppm}$ increased total carbohydrates percentage in different plant organs (leaves, fruits and roots) in the second season. These results are in agreement with those obtained by Kassem (2002) on rosemary.

Amino acids (tryptophan and methionine) increased total carbohydrates percentage in leaves in the first season, in fruits and roots in both two seasons, but decreased total carbohydrates percentage in the leaves in the second season. These results are in harmony with those obtained by Milad (1998) who found that total carbohydrates percentage were increased in the leaves of Mentha viridis, Mentha longifolia and Ocimum canum by tryptophan at 25,50 and $100 \mathrm{ppm}$.

Interaction between zinc at 50ppm and tryptophan at $50 \mathrm{ppm}$ was the most effective treatment on increasing total carbohydrates percentage in both leaves and fruits. Zinc at $100 \mathrm{ppm}$ or tryptophan at $100 \mathrm{ppm}$ was the most effective treatment on total carbohydrates percentage in the roots in both seasons.

\section{REFERENCES}

Abd El-Salam, I. Z. (1999): Physiological studies on fennel Plant (Foeniculum vulgare, Mill) plants. Ph.D. Thesis, Fac. Agric., Cairo Univ., Egypt.

Abou-Zeid, M. H ; S. K. Ahmed and M. R. Khater. (1996): Study on the effect of zinc treatments on fruits yield, oil percentage and its chemical constituents of fennel (Foeniculum vulgare, Dulce). Egyptian J. Appl. Sci., 11(9): 135-145.

Aziz, E.E and S. E. El-Sherbeny (2004): Effect of some macro and micro-nutrients on growth and chemical constituents of Sideritis montana, L. as a new plant introduced into Egypt. Arab Universities. Journal of Agricultural Sciences. 12(1): 391-403.

British Pharmacopoeia (1963): Determination of volatile oil in drugs. The Pharmaceutical Press 17 Bloomsbury. Square London, W.C.L.

Bunzen,J. ; N. Guichard ; J. Labbe ; P. Prevot ; J. Sperpinet and J. Trenchant (1969): Practical Manual of Gas Chromatography. El- Seiver Publ.Com., Amesterdam, London. 
El-Sawi, S.A. and M.A. Mohamed (2002): Cumin herb as a new source of essential oils and its response to foliar spray with some micro-elements. Food Chemistry, 77(1) : 75-80 .

El-Shorbaguy, M.S.M. (1979): Studies on the effect of some agricultural treatments on anise ( Pimpinella anisum, L.). M. Sc. Thesis El- Minia Univ., Egypt.

Guenther, E.(1968): The Essential Oils. 6 vols. D. Van Nostrand Company, Inc. New York. pp.578 - 584.

Harridy, I. M. A. (1986): Physiological studies on Periwinkle plant, Catharanthus roseus, G. Don. Ph.D. Thesis, Fac. Agric., Cairo Univ. Egypt.

Herbert, D.; P. J. Phipps and R. E. Strange (1971): Determination of total carbohydrates. Methods in Microbiology, 5 (B): 290 - 344.

Jacoup, R.W. (1995): Effect of chemical fertilization on growth and oil yield of sweet basil (Ocimum basilicum, L.) plants. M. Sc. Thesis, Fac. Agric., Cairo Univ., Egypt.

Jakson,M.L.(1967). Soil Chemical Analysis Prentice-Hall. Inc. England. Cliffs, U.S.A., pp 219-221.

Kassem, A.H.M. (2002): Effect of planting distances and some trace elements on rosemary plant. Ph.D. Thesis, Fac. Agric., Cairo Univ., Egypt.

Khalil, M. Y.; N. Y. Nagiub and S. E. El- Sherbeny (2002): Response of Tagetes erecta, L. to compost and foliar application of some micro-elements. Arab Univ. J. Agric. Sci., 10(3): 939 - 964.

Leung, A. Y. and S. Foster (1996): Encyclopedia Of Common Natural Ingredients Used In: Food, Drugs and Cosmetics. A Wiley Interscience Publication. John Wiley and Sons, Inc. pp. $119-121$.

Masada, Y. (1976): Analysis of Essential Oils by Gas Chromatography and Mass Spectrometry. Halsted Press Book. John Wiley \& Sons, Inc. New York. pp. $83-87$.

Milad, S.M.N. (1998): Effect of tryptophan and methionine on the productivity of two Mentha species and American Ocimum plants. M. Sc. Thesis, Fac. Agric., Cairo Univ., Egypt.

Misra, A ; A. K. Srivastava ; N. K. Srivastava and A. Khan (2005): Zn-acquisition and its role in growth, photosynthesis, photosynthetic pigments, and biochemical changes in essential monoterpene oils of Pelargonium graveolens. Photosynthetica, 43(1): 153-155.

Mohamed, M.I.(2000): Physiological studies on Coriandrum sativum, L. and Carum carvi, L. plants. Ph.D. Thesis, Fac. Agric., Cairo Univ., Egypt.

Mohamed, R.A.. (2003): Effect of some amino acids, trace elements and irradiation on fennel (Foeniculum vulgare, L.). M. Sc. Thesis, Fac. Agric., Cairo Univ., Egypt.

Mohamed, S. L. M. (1998): Effect of soil type and micronutrients on growth, yield and chemical constituents of Nigella sativa, L. Ph. D. Thesis, Fac. of Agric., Cairo Univ. Egypt. 
Naguib, N.Y.; M. Y. Khalil and S. E. El-Sherbeny (2003): The influence of Indole acetic acid, phenylalanine and methionine on growth, amino acid, and alkaloid production of periwinkle (Catharanthus roseus G. Don) plants. Bull. Fac. Agric. Cairo Univ., 54(2): 217-237.

Rao, B.R.R and S. Chand (1996): Response of lemon grass to zinc application. Journal of the Indian Society of Soil Science,44 (2) : 344 - 346.

Snedecor,G.W. and W. G. Cochran (1982). Statistical Methods. (6th Ed.) Iowa stat. Univ. Press. Ames. Iowa U.S.A.P.953.

Talaat, I. M.(2005): Physiological response of Lavandula angiostifolia, L. Plants to cysteine and nicotineamide. J. Agric. Sci. Mansoura Univ., 30(3): 1573-1582.

Talaat, I. M.; M. A. Beketa and M. H. Mahgoub (2005): Physiological response of periwinkle plants ( Catharanathus roseus, L.) to tryptophan and putrescine. International J. of Agriculture and Biology, 7(2): 210-213.

Zedan, H.M.Z. (2000): Effect of tryptophan and paclobutrazol on caraway (Carum Carvi, L.) and coriander (Coriandrum sativum, L.) plants. M. Sc. Thesis, Fac. Agric., Cairo Univ., Egypt. 


\section{تأثير الزنك والأحماض الأمينية علي النمو والمحصول والتزكيب الكيماوي في

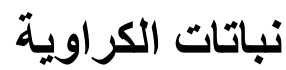

عبد الغفور عوض السيد* ـ أحمد سلامه الليثي* ـ محمد صلاح المختار الثوربجي** ـ

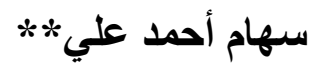

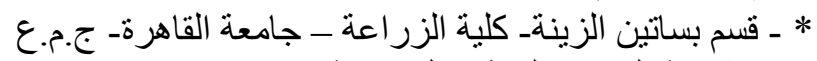

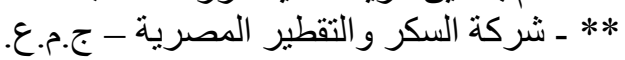

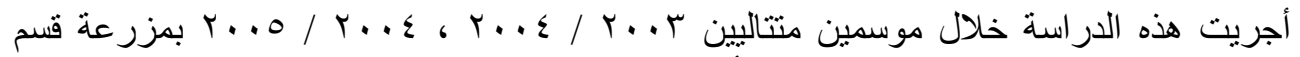

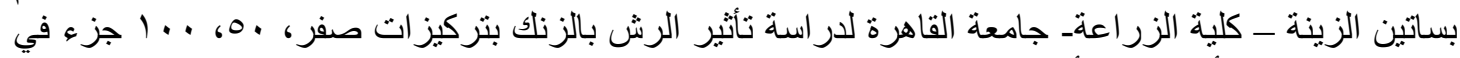

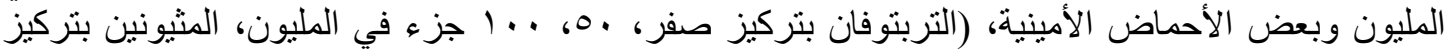

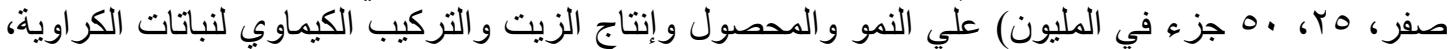

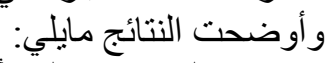

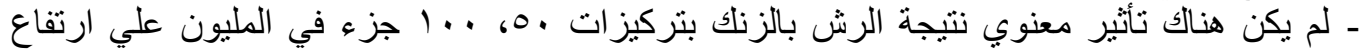

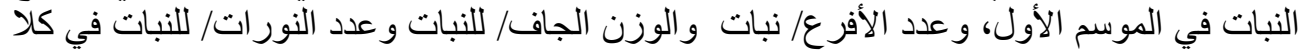

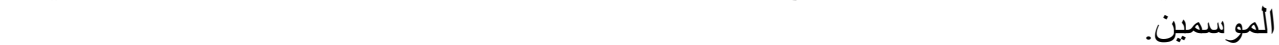
- بينما أدي الرش بالزنك بتركيز •ه جزء في المليون إلي زيادة معنوية في إرتفاع النبات والوزن

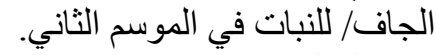

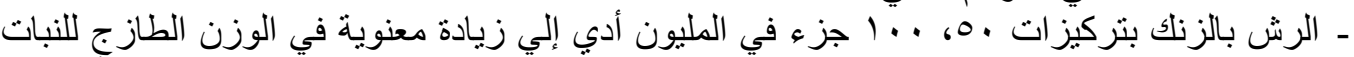

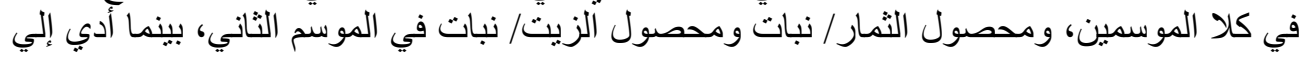

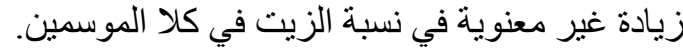

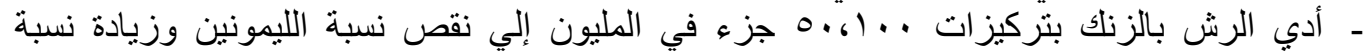

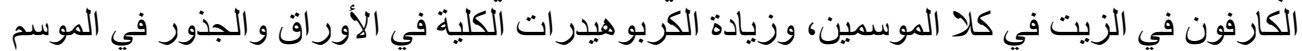

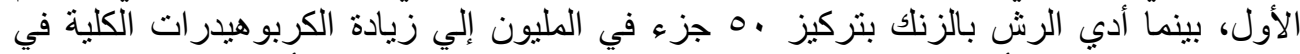

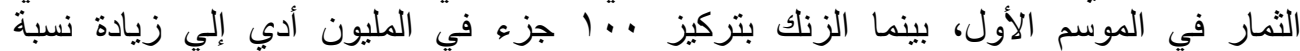

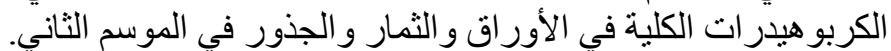

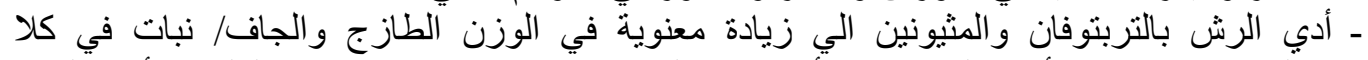

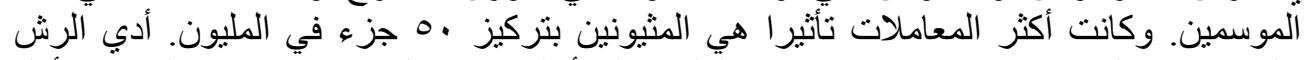

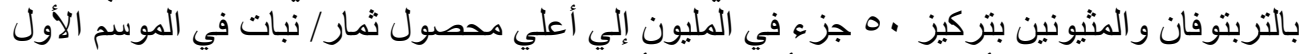

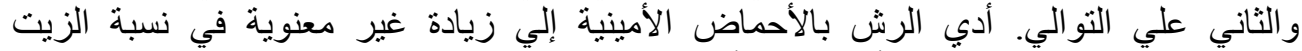

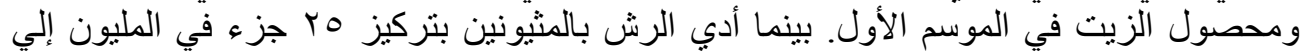

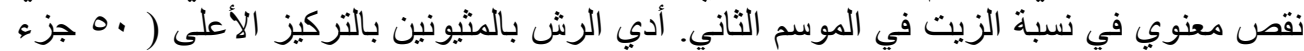

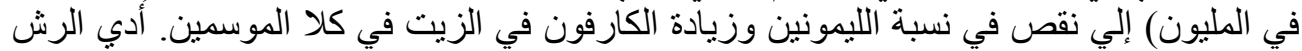

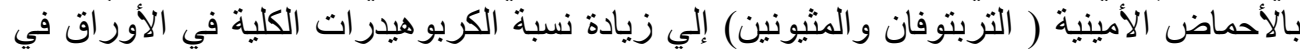
الموسم الأول، وفي الثمار و الجذور في كلان الألاني الموسمين.

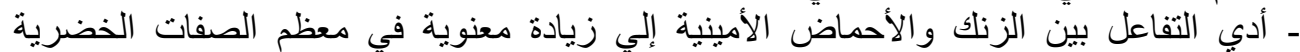

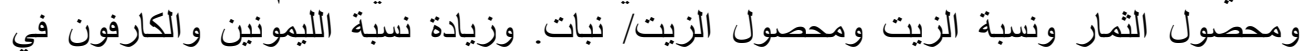
الزيت، ومحتوي النبات من الكربو هيدر ومن الزيت الكلية. 